\title{
Development of a New and Improved Guanidine-based Rac1 Inhibitor with in Vivo Activity against Non-Small Cell Lung Cancer
}

Matías S. Ciarlantini, ${ }^{[a]}$ Andrea Barquero, ${ }^{[b, c]}$ Juan Bayo, ${ }^{[d]}$ Diana Wetzler, ${ }^{[b, c]}$, Martín M. Dodes Traian, ${ }^{[b, c]}$ Hernán A. Bucci, ${ }^{[b, c]}$ Esteban J. Fiore, ${ }^{[d]}{ }^{[d u c i ́ a ~ G a n d o l f i ~ D o n a d i ́ o, ~}{ }^{[a, e]}$ Lucas Defelipe $^{[b, c]}$ Adrián Turjanski, ${ }^{[b, c]}$ Javier A. Ramírez, ${ }^{[f, g]}$ Guillermo Mazzolini, ${ }^{[d, h]}$ and Maria J. Comin*[a,e]

[a] M. S. Ciarlantini, Dr. L. Gandolfi Donadio, Dr. M. J. Comin

Departamento de Ingredientes Activos y Biorrefinerías

Instituto Nacional de Tecnología Industrial

Av. General Paz 5445, B1650WAB San Martin, Buenos Aires (Argentina)

E-mail: jcomin@inti.gob.ar

[b] Dr. A. Barquero, Dr. D. Wetzler, Dr. M. M. Dodes Traian, Dr H. A. Bucci, Dr. L. Defelipe, Dr. A. Turjanski

Departamento de Química Biológica

Facultad de Ciencias Exactas y Naturales, Universidad de Buenos Aires

Ciudad Universitaria, C1428EGA Ciudad Autónoma de Buenos Aires (Argentina)

[c] Dr. A. Barquero, Dr. D. Wetzler, Dr. M. M. Dodes Traian, Dr. H. A. Bucci, Dr. L. Defelipe, Dr. A. Turjanski

Consejo Nacional de Investigaciones Científicas y Técnicas (CONICET)- Universidad de Buenos Aires

Instituto de Química Biológica de la Facultad de Ciencias Exactas y Naturales (IQUIBICEN).

Ciudad Universitaria, C1428EGA Ciudad Autónoma de Buenos Aires (Argentina)

[d] Dr. J. Bayo, Dr. E. J. Fiore, Dr. G. Mazzolini

Gene Therapy Laboratory

Instituto de Investigaciones en Medicina Traslacional, Facultad de Ciencias Biomédicas, Consejo Nacional de Investigaciones Científicas y Técnicas (CONICET)

Universidad Austral, B1630FHB Derqui-Pilar (Argentina)

[e] Dr. L. Gandolfi Donadio, Dr. M. J. Comin

Consejo Nacional de Investigaciones Científicas y Técnicas (CONICET)

Av. General Paz 5445, B1650WAB San Martin, Buenos Aires (Argentina)

[f] Dr. J. A. Ramirez

Departamento de Química Orgánica

Facultad de Ciencias Exactas y Naturales, Universidad de Buenos Aires

Ciudad Universitaria, C1428EGA Ciudad Autónoma de Buenos Aires (Argentina)

[g] Dr. J. A. Ramirez

Consejo Nacional de Investigaciones Científicas y Técnicas (CONICET) - Universidad de Buenos Aires

Unidad de Microanálisis y Métodos Físicos Aplicados a Química Orgánica (UMYMFOR)

Ciudad Universitaria, C1428EGA Ciudad Autónoma de Buenos Aires (Argentina)

[h] Dr. G. Mazzolini

Liver Unit

Hospital Universitario Austral

B1629AHJ Derqui-Pilar, Buenos Aires (Argentina)

Supporting information for this article is given via a link at the end of the document.

Abstract: The Rho GTPase Rac1 is involved in the control of cytoskeleton reorganization and other fundamental cellular functions. Aberrant activity of Rac1 and its regulators is common in human cancer. In particular, deregulated expression/activity of Rac GEFs, responsible for Rac1 activation, has been associated to a metastatic phenotype and drug resistance. Thus, the development of novel Rac1-GEF interaction inhibitors is a promising strategy for finding new preclinical candidates. Here, we studied structure-activity relationships within a new family of N,N'-disubstituted guanidine as Rac1 inhibitors. We found that compound 1D-142, presents superior antiproliferative activity in human cancer cell lines and higher potency as Rac1-GEF interaction inhibitor in vitro than parental compounds. In addition, 1D-142 reduces Rac1-mediated TNFa-induced NF-KB nuclear translocation during cell proliferation and migration in NSCLC. Notably, 1D-142 allowed us to show for the first time the application of a Rac1 inhibitor in a lung cancer animal model.

\section{Introduction}

Rho family of small guanosine triphosphatases (Rho GTPases) are critical regulators of cellular functions that play important roles in cancer progression. ${ }^{[1,2]}$ Between them, Rac GTPases (Rac1, Rac2, and Rac3) have been recognized as important nodes in signaling networks that control malignant transformation and the metastatic dissemination of cancer cells. ${ }^{[3]}$ Particularly, most of the functions of the Ras-related C3 botulinum toxin substrate 1 (Rac1) such as the control of the actin cytoskeleton reorganization, cell proliferation, adhesion and migration are considered essential for tumor growth and dissemination. ${ }^{[4]}$

As most Rho GTPases, Rac1 acts as a molecular switch by cycling between inactive (GDP-bound) and active (GTP-bound) conformations. In their GTP-bound state, small GTPases bind effectors to activate biochemical responses. This cycle is tightly regulated by three main types of proteins: guanine nucleotide exchange factors (GEFs), GTPase activating proteins (GAPs) and guanine nucleotide dissociation inhibitors (GDIs). The crucial step in Rac1 activation is the displacement of GDP by the action of GEFs, followed by binding to GTP normally present at high cytosolic concentrations. Several other regulation mechanisms such as post-translational modifications or interactions with scaffold proteins add further complexity to Rac1 activity orchestration. ${ }^{[5]}$

Deregulation of Rho GTPase function in cancer is associated with fundamental hallmarks of progression, including changes in gene expression, cell survival, oncogenic transformation, tumor metabolism and invasiveness. ${ }^{[6]}$ In this sense, Rac1 overexpression and/or hyperactivation has been reported in 
several cancers with high mortality rates, including prostate, bladder, gastric, liver, pancreatic, and lung cancer..$^{[2,7]}$ Additionally, a gain-of-function mutation named Rac1P29S, was found in a subset of melanomas, breast cancers and head and neck tumors. ${ }^{[8]}$ Recently, it was found that Rac1 shows increased expression in lung cancer tissues compared with normal tissues and that its overexpression is associated with high tumor node metastasis (TNM) stage, and poor differentiation in non-small cell lung cancer (NSCLC) patients. ${ }^{[9]}$ Besides, epidermal growth factor receptor (EGFR) activates Rac1 via inducing the accumulation of its specific GEF, T-cell lymphoma invasion and metastasis 1 (Tiam1), in NSCLC cells. ${ }^{[10]}$ Despite these findings, there are not previous data exploring Rac1 inhibition as a potential therapeutic strategy for lung cancer treatment.

Rho GTPases have been previously considered "undruggable" due to their globular structure with limited small-molecule binding pockets and its high picomolar affinity for GTP or GDP binding combined with the micromolar levels of GTP available in cells. ${ }^{[11,12]}$ However, in the last years, several strategies to achieve Rac1 inhibition have been developed. Between them, impairing the interaction of Rac1 with its GEFs has showed the highest success. ${ }^{[13]}$ GEF-induced activation is the most common mechanism for signal-mediated GTPase activation. Frequently, this process is driven by aberrant signaling from growth factor receptors and/or GEFs upregulation or mutation. In this regard, many GEFs present a relevant role in cancer and Rac1-GEF increased expression and/or activity appears to be a common phenomenon during cancer progression. ${ }^{[11]}$ Therefore, targeting the Rac-GEF binding turns to be an appealing rational strategy to inhibit the GTPase activity and thus cancer invasion. In addition, the specific Rac1-GEF Tiam1 is crucial for cell-cell adhesion and cell migration. Numerous studies demonstrated that Tiam1-Rac signaling activation plays a crucial role in enhancing invasion and metastasis of various cancers. ${ }^{[14]}$ Hence, several small molecules have been developed taking this particular protein-protein interaction (PPI) as molecular target by us $^{[15]}$ and others. ${ }^{[16-18]}$

The first reported selective inhibitor, NSC23766, was identified from a structure-based virtual screening of compounds that fitted into the surface groove of Rac1 critical for Tiam1 and Trio GEF interaction. In vitro, NSC23766 effectively inhibits Rac1 binding and activation by these Rac-specific GEFs in a concentrationdependent manner without interfering Cdc42 or RhoA activation. It also potently blocks serum or platelet-derived growth factor (PDGF)-induced Rac1 activation and lamellipodia formation. ${ }^{[16]}$ Treatment of cells in culture with NSC23766 blocks invasion and metastasis of multiple different tumor types. ${ }^{[19-21]}$ However, offtarget effects in mouse platelets, such as receptor downregulation, ${ }^{[22]}$ as well as the high $\mathrm{IC}_{50}(\sim 50 \mu \mathrm{mol} / \mathrm{L})$ of NSC23766 make it ineffective for pharmacologic use. Therefore, several other new compounds were developed looking for more potent Rac1 inhibitors. Ferri and colleagues developed ZINC07949036 and compound $4^{22}$ with improved cellular activity. ${ }^{[23]}$ Besides, further optimization of the chemical structure of NSC23766 led to the identification of better inhibitors, such as EHop-016, which represents a highly potent Rac1 inhibitor with an $\mathrm{IC}_{50}$ of $1.1 \mu \mathrm{M} \cdot{ }^{[18]}$ The efficacy of EHop-016 has been subsequently validated in several cancer cell lines. However, its relatively high effective concentrations and its moderate bioavailability ( $30 \%$ with $t_{1 / 2}$ of 4.5 hours) limited further development. ${ }^{[24]}$ Therefore, additional optimization led to MBQ167 one of the most potent Rac and Cdc42 inhibitor currently described in the literature. MBQ-167 inhibited Rac1/2/3 activity in the sub-micromolar range in vitro and in immunocompromised mouse models, $M B Q-167$ prevents mammary tumor progression 10-fold more potently than Ehop-016, although additional effects from an unknown alternate mechanism were also identified. ${ }^{[25]}$<smiles>Cc1cc(C)cc(NC(=N)Nc2ccccc2C(F)(F)F)c1</smiles>

Figure 1. Chemical structures of our previously identified guanidine-based Rac1 inhibitors.

In our previous work, a set of 200.000 drug-like known compounds from ZINC database was screened in silico in order to find candidates able to interact with Trp56 of Rac1, a residue that is known to be critical for GEF binding. ${ }^{[26]}$ Using this approach, compound ZINC69391 (1) (Figure 1) was selected for in vitro evaluation showing a significant antiproliferative effect on several cancer cell lines. Moreover, taking this first-in-class guanidinebased Rac1 inhibitor as starting point, some exploratory chemical modifications yielded $1 \mathrm{~A}-116$ (2) as a second generation compound which displayed more potent activity in cancer cells and in vivo tumor mice models. ${ }^{[15,27]}$ Additionally, $1 \mathrm{~A}-116$ showed selective pro-apoptotic activity in malignant glioma and in human acute leukemic human cell lines. ${ }^{[28,29]}$ Furthermore, employing this analogue as biochemical tool, it was shown that Rac1-PAK1 axis inhibition restores tamoxifen sensitivity in human resistant breast cancer cells. In this sense, $1 \mathrm{~A}-116$ effectively restored tamoxifen anti-proliferative effects and switched off PAK1 activity. ${ }^{[30]}$

A detailed computational study suggested that albeit both compounds show essentially the same interactions with the protein, a decrease of the free energy of solvation when the pyrimidine ring of ZINC69391 was replaced by a hydrophobic benzene ring in $1 \mathrm{~A}-116$ might account for a greater binding affinity of the later compound, thus leading to an increase in potency. ${ }^{[15]}$ Nevertheless, the high hydrophobicity of $1 \mathrm{~A}-116$ might impair its bioavailability, according to the widely accepted criteria for druglike compound selection.

Here, we explore the chemical space surrounding ZINC69391 and $1 \mathrm{~A}-116$ and perform several in vitro and in vivo assays with the aim of finding a more potent and improved Rac1 inhibitor targeting the interaction with its activating protein Tiam1. In addition, we investigate for the first time the potential utilization of Rac1 inhibitors in vitro and in vivo for the treatment of non-small cell lung cancer. 

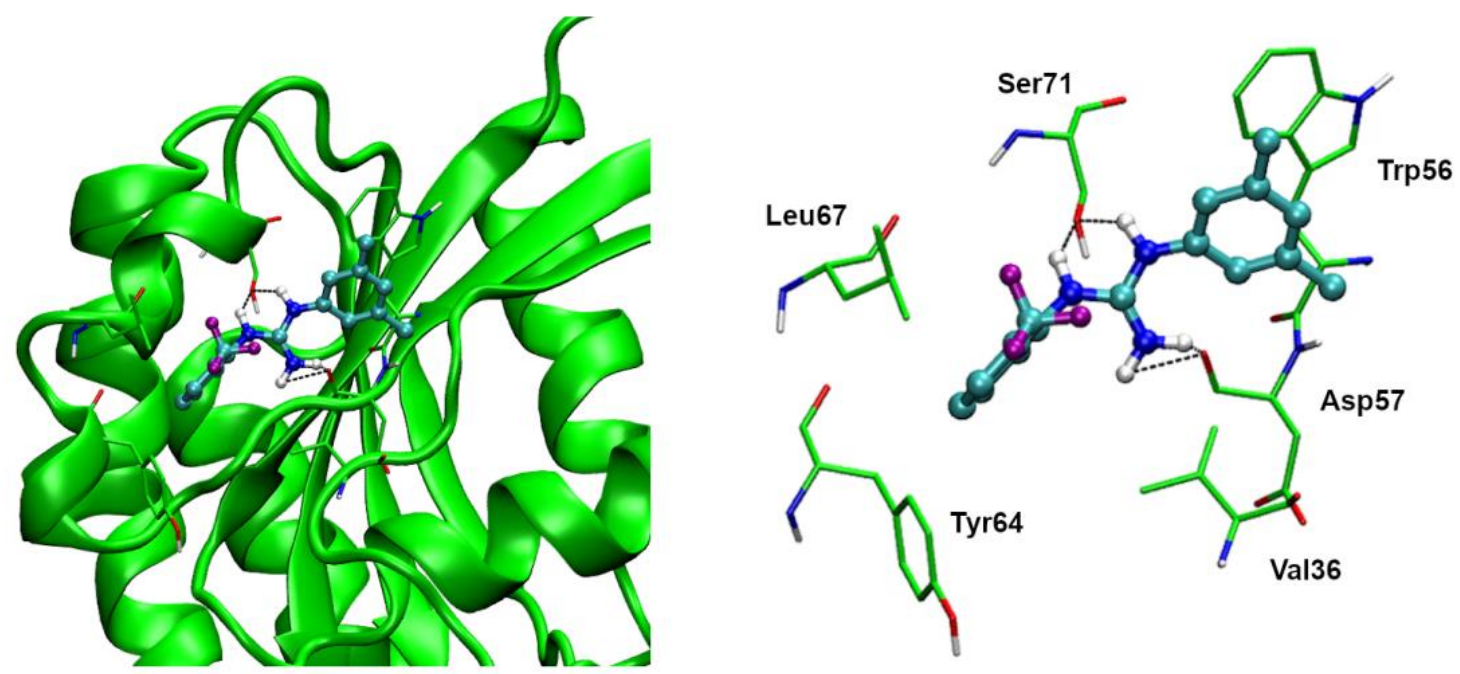

Figure 2. Docked structure of $1 \mathrm{~A}-116$ on Rac1 Trp56-bearing surface cavity. It shows two double hydrogen bonds between the H-donor guanidine moiety and acceptors Asp57 and Ser71, and the $\pi$ - $\pi$ stacking interaction between 3,5-dimethylphenyl group and Trp56 indole side chain. Additionally, 2 -(trifluoromethyl)pheny ring places into a hydrophobic region delimited by Val36, Tyr64 and Leu67 residues.

\section{Results and Discussion}

\section{Design of the compounds}

Docking simulation studies showed that in both cases the guanidinium moiety present in ZINC69391 and 1A-116 interacts through four hydrogen bonds with Rac1 residues Ser71 and Asp57, positioning them in such a way that they can establish a hydrophobic interaction with key residue Trp56, known to be essential for Rac1-GEF binding (Figure 2).

Thus, we designed a virtual library of $\mathrm{N}, \mathrm{N}^{\prime}$ - disubstituted guanidines where the trifluoromethylphenyl or pyrimidine ring were alternatively maintained while the other guanidine substituent was varied between either aliphatic, aromatic or heteroaromatic fragments, seeking to explore a wide region of the chemical space. Compounds were docked onto Rac1 Trp-56bearing surface cavity and those who showed favorable binding energy were analyzed in terms of Lipinsky's and Veber's rules. Following this strategy, a subset of nineteen new compounds was selected for synthesis (Figure 3A). In order to gain further insight into the diversity of the library, we performed an additional chemoinformatic analysis in which 15 suitable molecular descriptors, meant to grasp the topological, structural and physicochemical properties of a set of compounds, were calculated (see SI file for details). These validated
A)

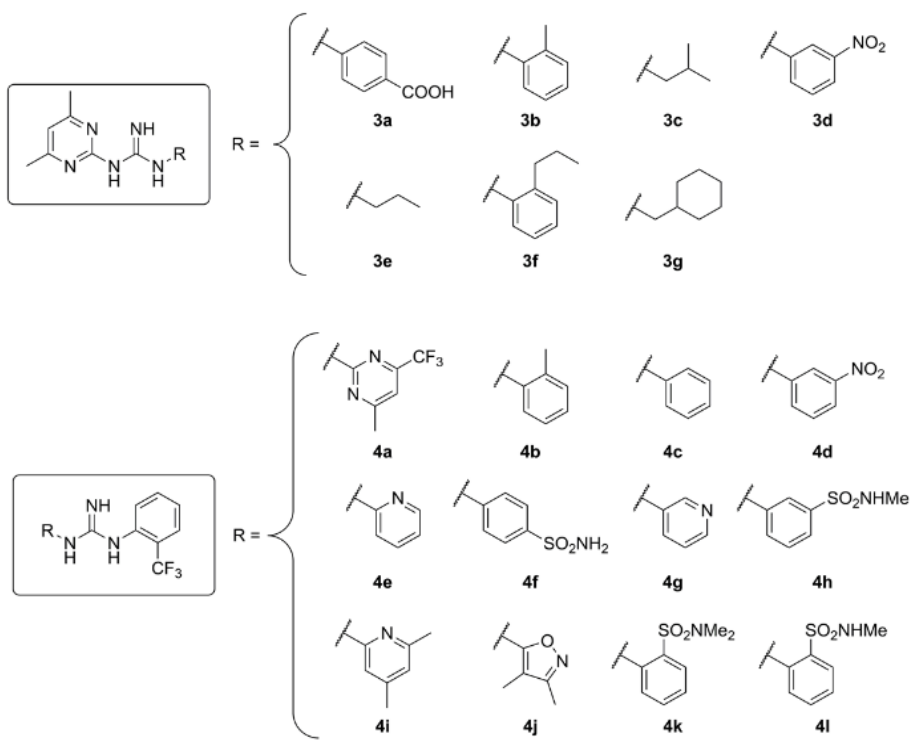

B)

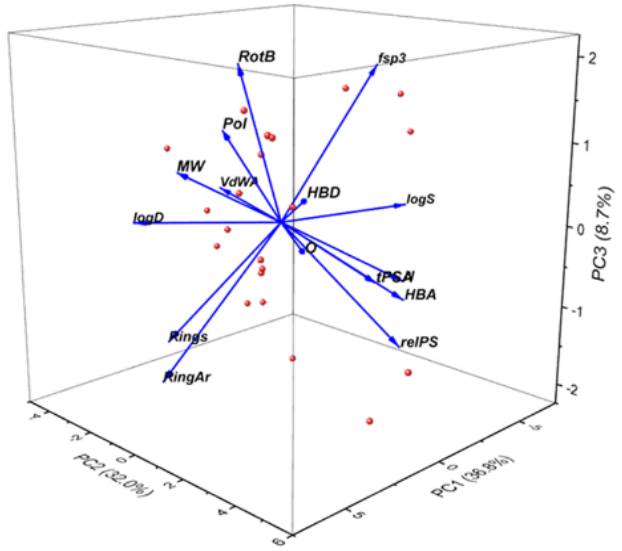

Figure 3. A) Chemical structures of top-scored potential Rac1 inhibitors selected by virtual screening. B) Three-dimensional biplot of principal component analysis (PCA). The relative position of the selected compounds is displayed, along with the contribution of the selected descriptors, reflecting the diversity of the library. 
descriptors, ${ }^{[31,32]}$ were taken as a base for a principal component analysis (PCA): the 15-dimension chemical space defined by these descriptors was projected onto 15 orthogonal axes (principal components), of which the first three (PC1, PC2 and PC3) allow to represent $77 \%$ of the initial variability of the data. Figure $3 \mathrm{~B}$ shows a tridimensional biplot (PC1 vs PC2 and PC3) and the relative position of the selected compounds, whose spanning across the chemical space defined by the descriptors chosen for the analysis reflects the diversity of the library

\section{Chemistry}

The use of cyanamides as starting material for the preparation of guanidines is a well stablished methodology. ${ }^{[33]}$ Thus, in order to synthesize compounds $\mathbf{3 a - h}$ we obtained the pyrimidine-bearing cyanamide $\mathbf{5}$ following previously reported methods in gram scale. ${ }^{[34]}$ With cyanamide $\mathbf{5}$ in hand, it was coupled with the corresponding amines (as hydrochlorides) to give the desired $\mathrm{N}, \mathrm{N}$ '-disubstituded guanidines with yields ranging from 50 to $75 \%$ (Scheme 1A). Compound $\mathbf{4 a}$ was prepared in a similar fashion employing 1,1,1-trifluoroacetylacetone for the synthesis of the corresponding cyamide 6 .

\section{A)}<smiles>[R]NC(=N)Nc1nc(C)cc(C)n1</smiles>

B)<smiles>O=C(NS(=O)(=O)c1ccccc1)c1ccccc1</smiles><smiles>Nc1ccccc1C(F)(F)F</smiles><smiles>CC(C)(C)[18OH]</smiles><smiles>O=C(NC(=S)Nc1ccccc1C(F)(F)F)c1ccccc1</smiles>

8 9 10<smiles>[R]N=C(NC(=O)c1ccccc1)Nc1ccccc1C(F)(F)F</smiles>

$11 \mathrm{e}-\mathrm{I}$
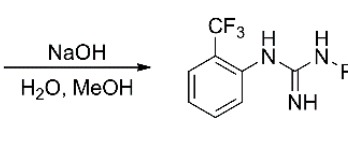

$4 e-1$

Scheme 1. A) Synthesis of 3,5-dimethyl pyrimidinyl derivatives (3a-g) and 2 trifluoromethyl phenyl derivatives (4a-d) employing cyanamides intermediates. B) EDCl-based synthesis of 2-trifluoromethyl phenyl derivatives $4 \mathrm{e}-\mathrm{I}$.

Nevertheless, when the same approach was employed for generating the subset of compounds $4 \mathbf{b}-\mathbf{I}$, we found that

cyanamide $7^{[35]}$ failed to efficiently couple with all anilines. In this sense, it allowed us to prepare fair amounts of 2trifluoromethylphenyl derivatives $\mathbf{4} \mathbf{b}$ - $\mathbf{d}$ but it failed when employed for the introduction of sulfonamide-substituted or heteroaromatic anilines leading to complex mixtures of by-products. In addition, in our hands, the scale up of cyanamide 7 synthesis proved to be challenging, its isolation usually implicated long purification chromatographic procedures and irreproducible yields at increasing scales. Therefore, we explored a different synthetic strategy based on the use of EDCI as coupling agent. EDCI has been used previously as thiocarbonyl activating reagent for the synthesis of carbamoyl and acyl guanidines among others dialkylated guanidine derivatives in mild conditions. ${ }^{[36,37]}$

As shown in Scheme 1B, the synthesis of benzoylated thiourea 10 was accomplished in good yields by treatment of in situ generated isothiocyanate 8 with commercially available 2trifluoromethyl aniline (9). Coupling of $\mathbf{1 0}$ with the corresponding amines employing EDCl as desulfurizing agent led to the benzoylprotected intermediates $11 \mathrm{e}-\mathrm{I}$ that, upon basic hydrolysis, afforded the desired products $4 \mathrm{e}-\mathrm{I}$ in variable fair to very good yields.

\section{Biological Evaluation}

\section{Identification of new guanidine analogue 4i/1D-142 with more} potent antiproliferative effect by cell-based assays

A set of nineteen new compounds were synthesized in order to explore the chemical space and optimize the biological activity of parent compounds ZINC69391 (1) and 1A-116 (2). Thus, to evaluate the antiproliferative profile of the new analogues, we selected a representative panel of five human cancer cell lines where Rac1 overexpression or hyperactivation has been associated with malignant transformation. ${ }^{37}$ They include A549 (epithelial lung carcinome), HT29 (epithelial colorectal adenocarcinome), PC3 (prostate adenocarcinome), A375 (epithelial skin melanoma) and MDA-MB-231 (epithelial breast adenocarcinome). We performed a first set of experiments at a single dose of $50 \mu \mathrm{M}$ during $72 \mathrm{~h}$ using standard MTT assays (Figure 4). Strikingly, several new analogues such as compounds $\mathbf{3 d}, \mathbf{3 f}, \mathbf{4 a}, \mathbf{4 e}$ and $\mathbf{4 i}$ showed improved activity when compared to 1A-116. In particular, derivative $4 \mathbf{i}$, from now on 1D-142, showed the highest proliferation inhibition in all cell lines assayed, with $\mathrm{IC}_{50}$ 's ranging from 8 to $15 \mu \mathrm{M}$.

As can be inferred from Table 1, IC $\mathrm{C}_{50}$ 's were 5 to 9 -fold lower when compared to $1 \mathrm{~A}-116$. These results suggest a potential improvement of the Rac1 inhibitory activity by the newly identified analogue. Therefore, as 1D-142 proved to be the most potent compound from this series, it was selected for further studies.

Table 1. Biological data for compounds $1 \mathrm{D}-142$ and $1 \mathrm{~A}-116$

\begin{tabular}{|c|c|c|c|c|c|}
\hline \multirow{2}{*}{ Compound } & \multicolumn{5}{|c|}{$\mathrm{IC}_{50}(\mu \mathrm{M})^{[\mathrm{a}]}$} \\
\hline & A549 & HT29 & PC3 & A375 & MDA-MB-231 \\
\hline 1D-142 & $7.8 \pm 0.4$ & $9.0 \pm 0.4$ & $9.3 \pm 0.3$ & $7.4 \pm 0.3$ & $14.6 \pm 0.4$ \\
\hline $1 A-116$ & $50 \pm 2$ & $83 \pm 2$ & $48 \pm 1$ & $51 \pm 1$ & $91 \pm 2$ \\
\hline
\end{tabular}

[a] $\mathrm{IC}_{50}=$ Drug concentration required to inhibit cell growth by $50 \%$. Data are expressed as the mean \pm SD from the dose-response curves of three independent experiments. 
A)

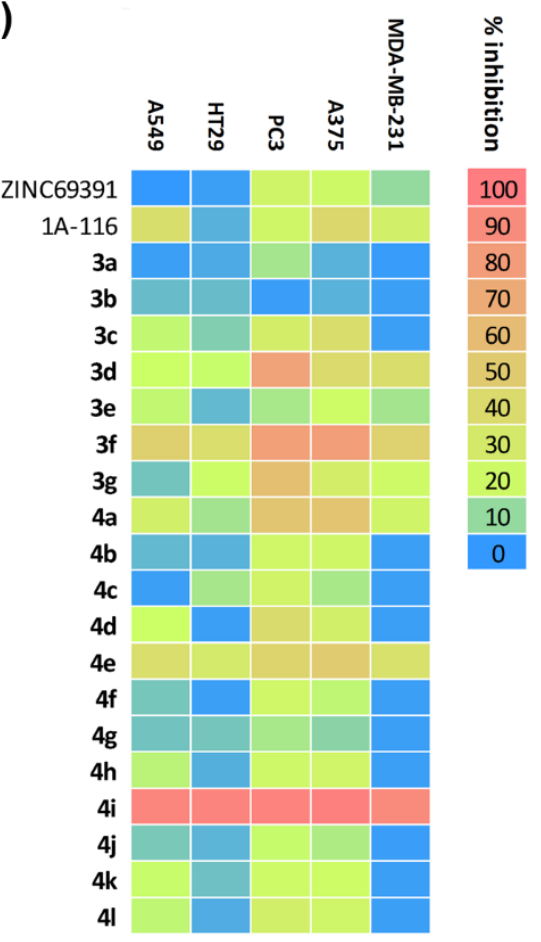

B)

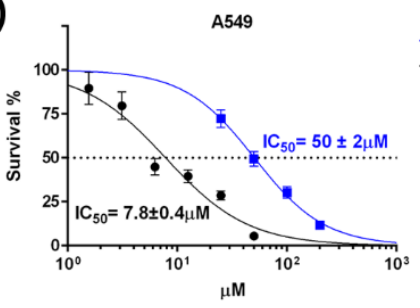

$-1 \mathrm{~A}-116$
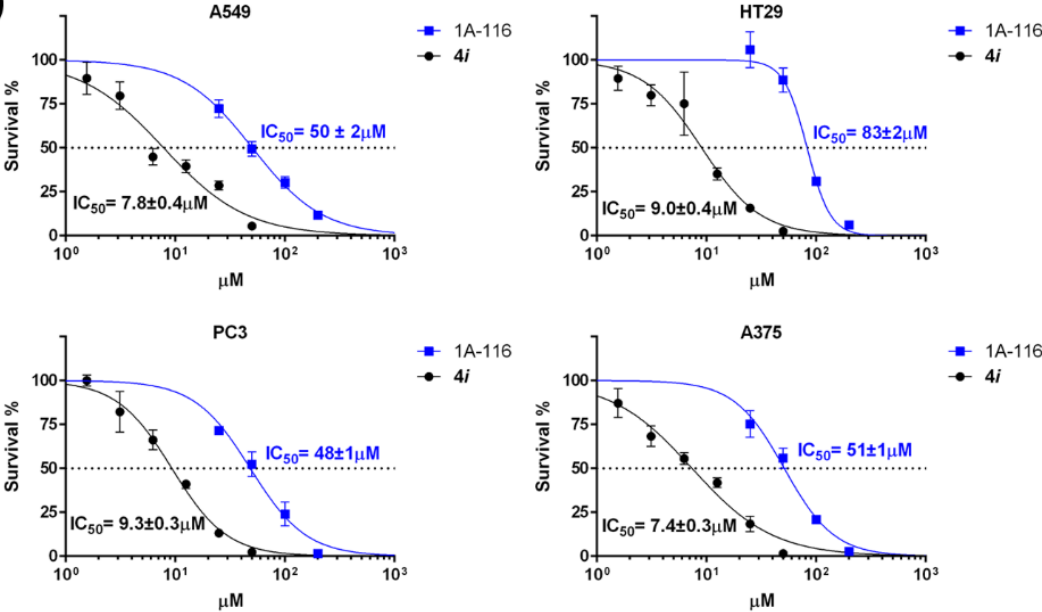

$-1 \mathrm{~A}-116$
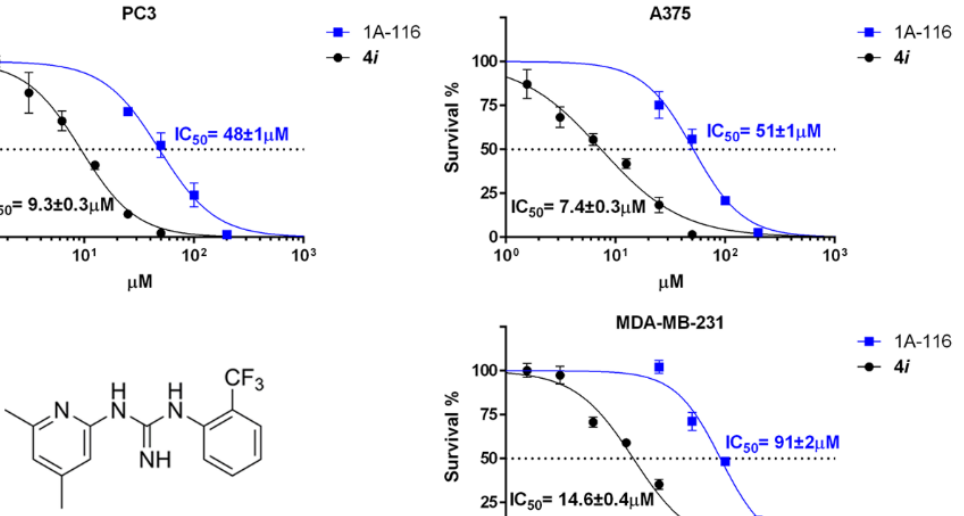

4i/1D-142

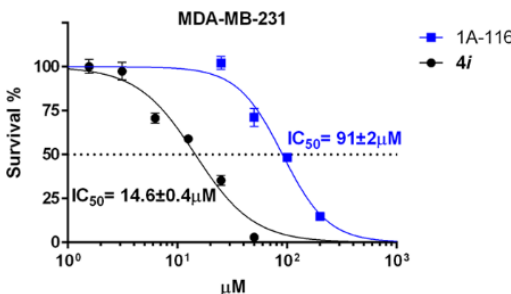

Figure 4. Antiproliferative activity against a panel of representative five human cancer cell lines. A) A549, HT29, PC3, A375 and MDA-MB-231 cells were treated with each compound at $50 \mu \mathrm{M}$ for $72 \mathrm{~h}$ and cell viability was evaluated by MTT assay. The growth inhibition was quantified as percentages for the five cell lines. B) Dose-response curves for cell viability in each cell line treated with $4 \mathrm{i} / 1 \mathrm{D}-142$ or $1 \mathrm{~A}-116$ for $72 \mathrm{~h}$ using MTT assay. The IC 50 values were determined as described in the Experimental section. The results are reported as the mean \pm standard deviation (SD) of three independent experiments.

\section{Compound 1D-142 inhibited Tiam1-catalyzed GDP/GTP exchange of Rac1 by interfering with protein-protein interaction}

In order to verify if $1 \mathrm{D}-142$ retains the ability of their parent compounds to interfere the Rac1-Tiam1 interaction, we developed a biochemical assay that allowed us to determine the inhibition of protein-protein complex formation. Thus, purified proteins were incubated with compound 1D-142 followed by complex affinity precipitation. The remaining Tiam 1 concentration in the soluble fraction was measured by Western blotting showing higher levels in the presence of inhibitor 1D-142 when compared to the control. In addition, the effect was dose-dependent and stronger than that observed for compound 1A-116 (Figure 5A).

After confirming that 1D-142 inhibited Rac1-Tiam1 interaction, we tested its effect on Tiam1-catalyzed GDP/GTP exchange of Rac1. For this purpose, we performed an in vitro nucleotide exchange assay following mant-GTP fluorescence increase produced upon Rac1 activation. In agreement with previous results, we found that under physiologic levels of $\mathrm{Mg}^{2+}$, Rac1 displays marginal mantGTP loading but demonstrates rapid nucleotide exchange when Tiam1 was added. ${ }^{[38]}$ The pre-incubation of Rac1 with increasing concentrations of

\section{A)}

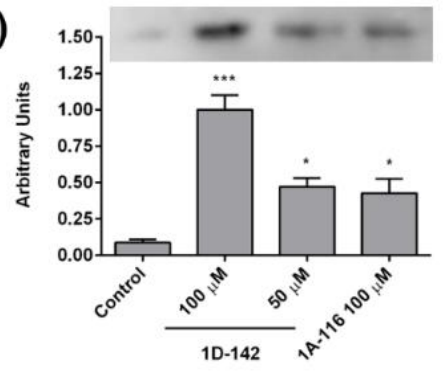

B)

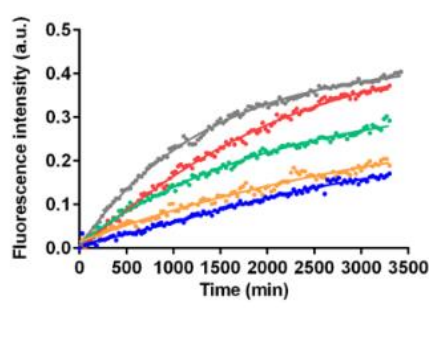

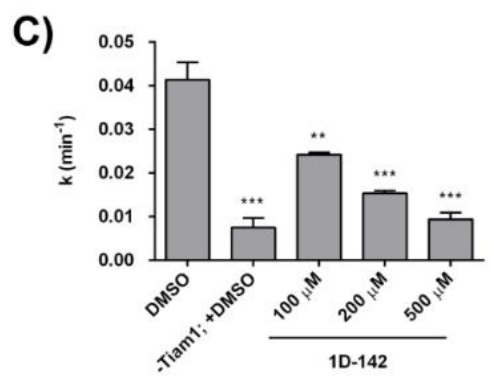

Figure 5. Effect of 1D-142 on Rac1-Tiam1 interaction and on Tiam1-catalyzed GDP/GTP exchange of Rac1. A) His-Tiam1/GST-Rac1 complex was affinityprecipitated with glutathione agarose beads in the presence of $1 \mathrm{D}-142(100$ and $50 \mu \mathrm{M})$ or $1 \mathrm{~A}-116(100 \mu \mathrm{M})$. Control experiment corresponds to the complex in the absence of any compound. Western blot analysis of the supernatants was carried out with anti-His antibody. Densitometric values are shown below (arbitrary units). Bars represent the average of three experiments $+S D$. ${ }^{*} p<0.05$ and ${ }^{* *} p<0.0011 D-142$ or $1 A-116$ vs Control by ANOVA. B) Representative fluorescence time trace in the presence of increasing concentrations of 1D-142 (100 $\mu \mathrm{M}$, red; $200 \mu \mathrm{M}$, green; $500 \mu \mathrm{M}$, orange). Time traces without 1D-142 (gray) and without Tiam1 (blue). C) Nucleotide exchange rates $(k)$ for time traces showed in $B$. Bars represent the average of three experiments $+S E M$. ${ }^{* *} p<0.01$ and ${ }^{* * *} p<0.0011 D-142$ or $1 \mathrm{~A}-116$ vs Control by ANOVA. 
1D-142 showed that it inhibited Tiam1-induced nucleotide exchange in a dose dependent manner (Figure 5B and 5C).

To understand the activity change between $1 \mathrm{~A}-116$ and 1D-142, we performed docking simulations over the crystal structure of Rac1. The structural difference between these two compounds resides in the transformation of the benzene ring to a pyridine ring. This change produces an increase in the predicted free energy of binding of $0.9 \mathrm{kcal} / \mathrm{mol}$ which could explain the observed difference in activity (See Supporting Info, Table S4). From a structural point of view, the change in energy can be pointed to the formation of an intramolecular hydrogen bond between the pyridine nitrogen and the guanidine moiety, which stabilizes the unfavorable high internal energy conformation for $1 \mathrm{~A}-116(+0.3$ $\mathrm{kcal} / \mathrm{mol})$ into a more favorable one for $1 \mathrm{D}-142(-0.7 \mathrm{kcal} / \mathrm{mol})$. Nevertheless, other processes could also explain the observed differences like metabolization or membrane permeability. In this sense, it is interesting to note that a biplot of the aforementioned PCA analysis shows that 1D-142 lies between 1A-116 and ZINC69391 in the chemical space, alongside the principal components PC2, which has a significant contribution of the $\log \mathrm{D}$ suggesting that hydrophobicity may also play a role in the modulation of biological properties, as discussed before (Figure $6)$.

\section{In-vitro characterization of 1D-142 antitumoral effect on human non-small cell lung carcinoma (NSCLC) A549 cells}

As previously mentioned, Rac1 has emerged as an attractive molecular target for the development of new therapies for lung cancer. Moreover, Rac1 activation appears to be a compensatory mechanism that results in the emergence of resistance to current available treatments including gefitinib. ${ }^{[39,40]}$ Considering that compound 1D-142 showed a potent antiproliferative activity in A549 lung cancer cell line, we conducted further experiments to gain insight into the underlying mechanism of action. First, we

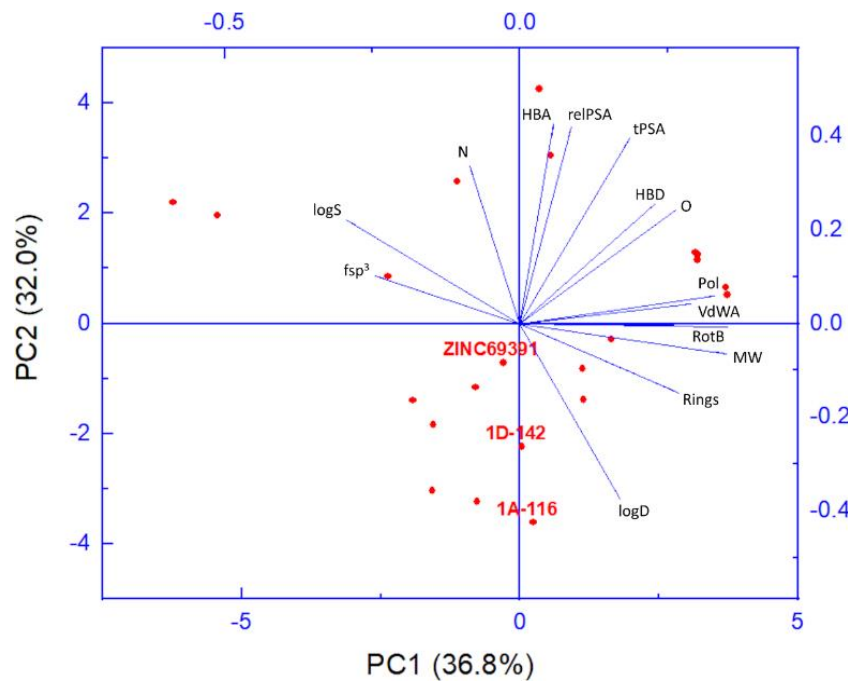

Figure 6. Biplot of $\mathrm{PC} 1$ vs $\mathrm{PC} 2$ showing that the $\log \mathrm{D}$ has a significant contribution to the relative position of compound 1D-142 in the chemical space when compared to ZINC69391 and 1A-116.

tested if 1D-142 inhibited the clonogenic capability of A549 cells in vitro. This assay might be regarded as an indirect estimation of the anti-neoplastic effect of a compound. ${ }^{[41]}$ As shown in Figure $7 \mathrm{a}, 1 \mathrm{D}-142$ strongly reduced the number of A549 colonies in a dose response manner.

Recently, it has been reported that $1 \mathrm{~A}-116$ was able to induce apoptosis in patient-derived leukemic cells. ${ }^{[29]}$ So, we wondered if the antitumoral effect observed for 1D-142 was due at least in part to apoptosis induction. A morphological analysis of dead cells showed that A549 cells treated for $24 \mathrm{~h}$ with 1D-142 exhibited apoptotic characteristics including nuclear condensation and fragmentation, cell shrinkage and
A)
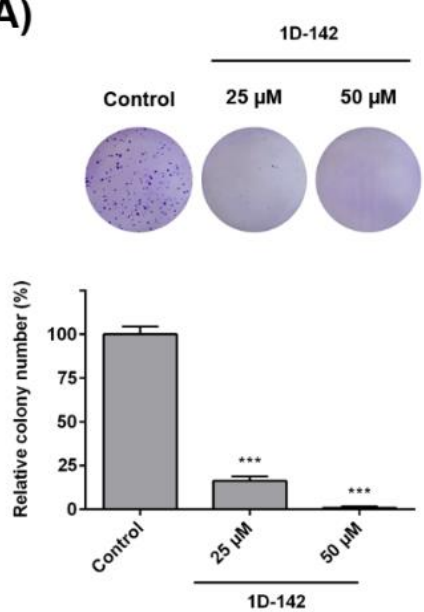

B)
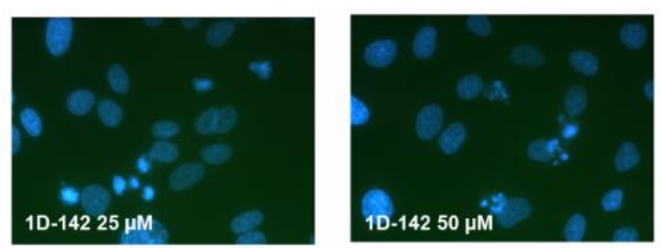

C)
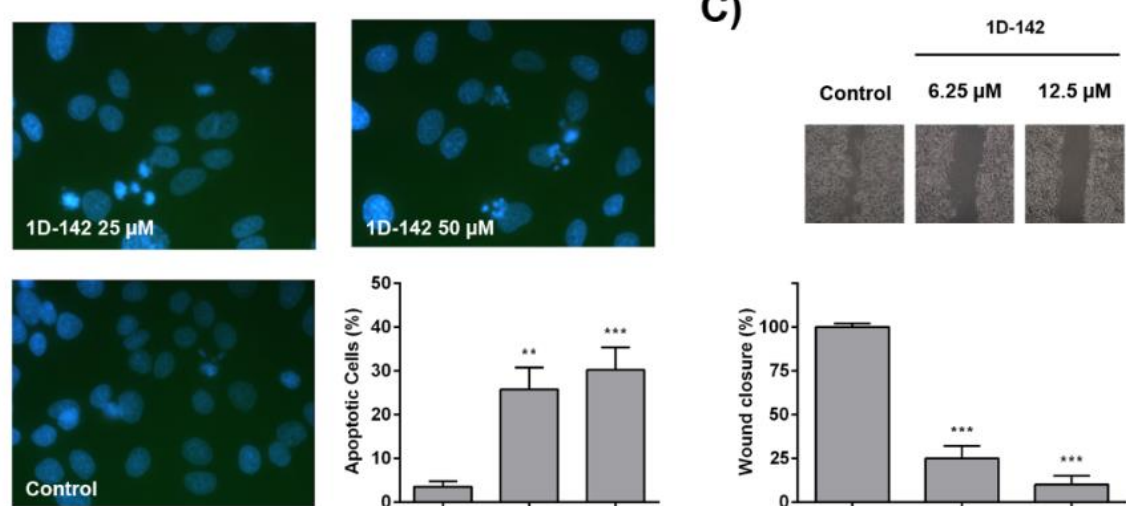
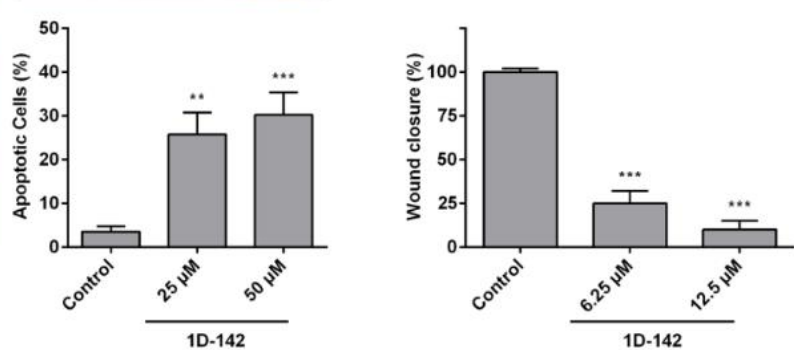

Figure 7. Antitumor effect of 1D-142 on A549 human non-small cell lung carcinoma cells. A) Clonogenic assay of A549 cells first treated with compound 1D-142 at indicated concentrations for $24 \mathrm{~h}$ and then cells were grown in drug-free medium for additional 7 days until visible colonies appeared. Representative photographs and percentage of colonies formed with respect to untreated control. Data are expressed as mean \pm SD of three independent experiments. ${ }^{* \star *} p<0.0011 \mathrm{D}-142$ vs Control by ANOVA B) Morphological analysis of cell death by DAPI staining. A549 cells were treated for $24 \mathrm{~h}$ with compound 1D-142 at the indicated doses. Representative fluorescence microscopy images taken at 400X and quantitative analysis of apoptotic cells. Results are presented as mean \pm SD of three separated experiments. ${ }^{* *} p<0.01$ and ${ }^{* * *} p<0.0011 D-142$ vs Control by ANOVA. C) Wound healing assay of A549 cells in the presence or not of $1 D-142$. Representative photographs taken at $48 \mathrm{~h}$ and results expressed as percentage of wound closure of three independent experiments. ${ }^{* *} \mathrm{p}<0.0011 \mathrm{D}-142$ vs Control by ANOVA. 
fragmentation into apoptotic bodies, with respect to untreated cells in a dose dependent manner (Figure 7B).

It is well stablished that Rho small GTPases are key regulators of cell movement and actin cytoskeleton reorganization. Particularly, Rac1 is a key regulator of cell migration and lamellipodia formation in NSCLC cells. ${ }^{[42]}$ In previous reports, it was shown that ZINC69391 was able to inhibit actin reorganization and cell migration of MDA-MB-231 and F3II cells. ${ }^{[15]}$ Thus, we next studied the effect of compound 1D-142 on A549 cells migration using a wound healing assay under non-toxic conditions. As shown in Figure $7 \mathrm{C}$ cells treated with $1 \mathrm{D}-142$ significantly reduced cell migration up to $90 \%$ compared to untreated control cells, with similar results for the highly metastatic MDA-MB-231 cell line (See Supporting Info), suggesting an anti-metastatic potential. Therefore, we demonstrate that 1D-142 in vitro treatment in NSCLC cells results in decreased colony formation and cell migration and it induces apoptotic cell death program.

\section{Compound 1D-142 abrogates TNFa-induced NF-KB nuclear translocation}

It was shown that cell proliferation and migration induced by Rac1 is mediated by NF-KB activation in NSCLC. ${ }^{[42]}$ Thus, we assessed if NF-KB activity was affected in A549 cells treated with 1D-142. NF-kB is a protein complex composed by two subunits sequestered in the cytoplasm in an inactive state by the inhibitory cytoplasmic binding protein $\mathrm{IkBa} .{ }^{[43]}$ Exposure of cells to various stimuli, such as TNF- $\alpha$, leads to the rapid phosphorylation and proteolytic degradation of $1 \mathrm{kBa}$, which triggers RelA/p65 (the transcriptionally active subunit of the NF-KB heterodimer) translocation into the nucleus and initiates gene transcription. Remarkably, immunofluorescence microscopy showed that 1D142 strongly inhibits the RelA/p65 translocation to the nucleus after TNF- $\alpha$ induction (Figure 8A).

Then, we wondered if the 1D-142 effect on RelA/p65 was mediated by the inhibition of $\mathrm{IKBa}$ degradation. Unexpectedly, pre-treatment with the same concentrations of $1 \mathrm{D}-142$ that inhibited RelA/p65 translocation had no effect on TNF- $\alpha$-induced IKBa degradation in whole A549 cell lysates (Figure 8B). Thus, these results indicate that $1 \mathrm{D}-142$ abrogates TNFa-induced NF$\mathrm{KB}$ activation through a mechanism that impedes RelA/p65 nuclear translocation but independently to $1 \mathrm{kB} \alpha$ degradation. Indeed, this finding may explain the previous observation that compound ZINC69391 decreases NF-KB transcriptional activity in human myeloid leukemia $\mathrm{HL}-60$ cell line, ${ }^{[29]}$ as well as the reduced TNFa-mediated NF-KB luciferase activity described in lung cancer cells treated with NSC23766. ${ }^{[42]}$

\section{Compound 1D-142 inhibits human non-small cell lung carcinoma (NSCLC) A549 cell line tumor growth in vivo}

Finally, we wondered whether 1D-142 exerts anticancer effects in vivo. Strikingly, A549 tumor bearing mice treated with 1D-142 showed a marked reduction of tumor growth in comparison with vehicle controls (Figure 9A). Even more, treatment with compound 1D-142 extended lifespan of tumor bearing mice to 95 days from the 63 days observed in the control mice group (Figure $9 \mathrm{~B})$. It should be noted that treatment with $1 \mathrm{D}-142$ did not adversely affected the weight of the mice during the experimental period (Figure 9C).
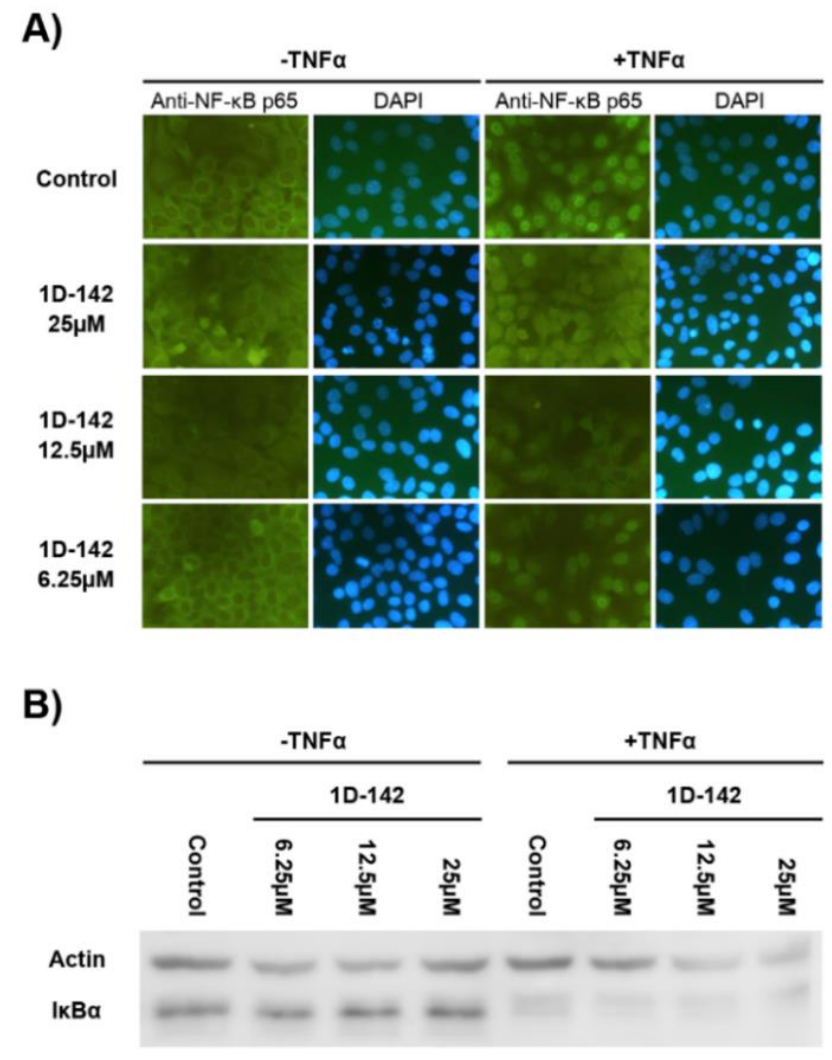

Figure 8. Effect of 1D-142 on A549 cells TNFa-induced NF-kB nuclear translocation. A549 cells were preincubated with $1 \mathrm{D}-142$ at indicated concentrations for $24 \mathrm{~h}$ and then treated with TNFa $(10 \mathrm{ng} / \mathrm{ml})$ at $37^{\circ} \mathrm{C}$ for 30 min. A) Cells were fixed and NF-kB nuclear translocation were visualized by immunofluorescence staining with anti-p65 antibodies. Nuclei were counterstained with DAPI. Magnification 400X. B) Cells were lysed and IKBa protein levels were analyzed by Western blot. Actin antibody was used as loading control.

\section{Conclusion}

In summary, we have achieved the exploration of the chemical space surrounding $\mathrm{N}, \mathrm{N}^{\prime}$-disubstituted guanidines which are promising yet underexploited scaffolds for the design of new Rac1 inhibitors. With the aid of computational tools, we generated a diverse library that was screened through a docking-based methodology, affording a set of compounds both energetically and conformationally promising. Selected compounds were synthesized and tested for antiproliferative activity on a panel of cancer cell lines, for which Rac1 overexpression or hyperactivation has been related to its aggressive phenotype. This led to the discovery of compound $1 \mathrm{D}-142$ as a new guanidine-based inhibitor with a significantly higher potency both in vitro and in vivo than previously reported derivative $1 \mathrm{~A}-116$. When compared to $1 \mathrm{~A}-116,1 \mathrm{D}-142$ was consistently 5 to 9 -fold more potent as antiproliferative agent in the five cell lines studied. By affinity precipitation and GDP/GTP exchange assays we showed that 1D-142 may inhibit Rac1 activation through the interference with Rac1-Tiam1 interaction in a concentrationdependent manner. We further studied the effect of 1D-142 on A549 NSCLC, a cell line that showed to be more resistant to treatment with our previously developed guanidine analogues. 
A)

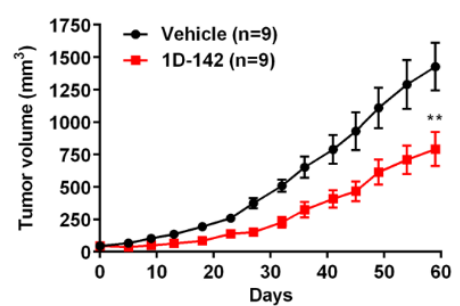

B)

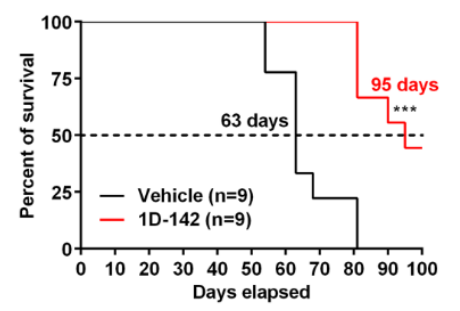

C)

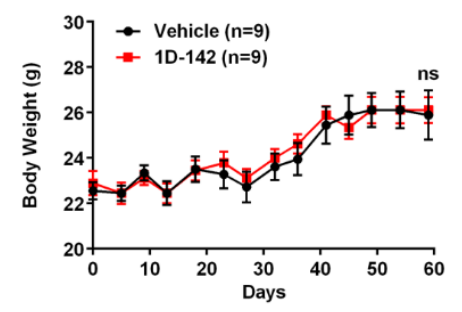

Figure 9. 1D-142 robustly reduces tumor volume in vivo and prolongs the survival of tumor bearing mice. Subcutaneous tumors generated from A549 cells were allowed to reach a volume of $50 \mathrm{~mm}^{3}$. Then, mice were treated every other day with vehicle $(\mathrm{n}=9)$ or $1 \mathrm{D}-14210 \mathrm{mg} / \mathrm{kg}(\mathrm{n}=9)$ until the end of the experiment. Graphs represents the tumor volume $(A)$, percent survival $(B)$ and the mice body weight $(C)$. Error bars represent $S E M$. ns $p>0.03$, ${ }^{\star *} p<0.01$ and ${ }^{* * *} p<0.0011 D-142$ vs Vehicle (2-way ANOVA for tumor growth and mice weight, and Kaplan-Meier for survival). Median survival is indicated in the graph for percent survival.

Remarkably, we found that treatment with 1D-142 not only inhibited the migration capability of A549 but also it was a strong pro-apoptotic inductor. Even more, 1D-142 treatment also reduced the TNFa-induced NF-kB nuclear translocation in NSCLC cells in a IKBa degradation independent manner. It is interesting to point out that the NF-KB pathway has been deeply related not only to Rac1 activity but also to lung carcinogenesis. ${ }^{[42]}$ Indeed, 1D-142 showed significant antitumor efficacy in vivo in an A549 xenograft model by reducing tumor growth and increasing animal survival, with no decrease in mice body weight. Overall, our results suggest that $1 \mathrm{D}-142$ is an appealing Rac1-Tiam1 interaction inhibitor for further development in the treatment of Non-Small Cell Lung Cancer.

\section{Experimental Section}

General Procedures: For a full experimental description of the synthesis and characterization of the new compounds, see the Supporting Information. All chemical compounds were purchased from commercial sources or synthesized. All final products were at least $95 \%$ pure, as determined by ${ }^{1} \mathrm{H}$ NMR. Reaction monitoring was performed on Merck silica gel 254F TLC plates. Column chromatography was performed on a Teledyne Isco CombiFlash $\mathrm{R}_{\mathrm{f}}{ }^{+}$instrument under gradient elution conditions with RediSep disposable flash columns. Infrared spectra were recorded on a Nicolet iZ10 spectrometer. All melting points were determined on an Electrothermal IA9000 series digital melting point apparatus and are uncorrected. ${ }^{1} \mathrm{H}$ NMR and ${ }^{13} \mathrm{C}$ NMR spectra were carried out on Bruker Fourier $300,300 \mathrm{MHz}$ or Bruker Avance DPX 400, $400 \mathrm{MHz}$ spectrometer using $\mathrm{CDCl}_{3}, \mathrm{MeOD}$ or DMSO- $d_{6}$ as the solvent and TMS as internal standard. High resolution positive ion electrospray ionization MS was conducted on a Waters Xevo G2S Q-TOF spectrometer operated at both positive and negative modes. Low resolution mass spectra were obtained either by EI on a Shimadzu QP2010 ultra spectrometer at ionization potential of $70 \mathrm{eV}$ or by ESI on a Waters Quattro Premier XE spectrometer. Elemental analyses were measured with an Exeter Analytical CE-440 Elemental Analyzer and were within $\pm 0.4 \%$ of the theoretical values for $\mathrm{C}, \mathrm{H}$, and $\mathrm{N}$. Elemental analyses were performed by UMYMFOR-CONICET. None of the tested compounds showed PAINS alerts. ${ }^{[44]}$

Compound 10 was obtained by adapting the procedure described by Rauf et. al. ${ }^{[45]}$

1-(4,6-dimethylpyridin-2-yl)-3-(2-(trifluoromethyl)phenyl)guanidine (4i/1D-142): To a solution of 4,6-dimethyl-2-aminopyridine (1,43 g; 11,69 $\mathrm{mmol}$ ), and benzoyl thiourea $10(2,51 \mathrm{~g} ; 7,75 \mathrm{mmol})$ in $100 \mathrm{~mL}$ of anhydrous $\mathrm{CH}_{2} \mathrm{Cl}_{2}$, triethylamine $(1,53 \mathrm{~mL} ; 10,76 \mathrm{mmol})$ and $\mathrm{EDCl}(4,45 \mathrm{~g}$; $23,21 \mathrm{mmol}$ ) were respectively added at $0 \stackrel{\circ}{ } \mathrm{C}$. The reaction mixture was stirred under Argon atmosphere. After 1 hour the ice bath was removed and the solution was stirred over night at room temperature. After completion of the reaction assessed by TLC, the mixture was washed with $1 \% \mathrm{HCl}(\mathrm{x} 2)$, water and brine. Organic phase was dried and evaporated under reduced pressure. The residue was dissolved in $\mathrm{MeOH}(130 \mathrm{~mL})$ and $10 \% \mathrm{NaOH}$ solution ( $180 \mathrm{~mL}$ ) was added. The mixture was vigorously stirred at $80^{\circ} \mathrm{C}$ for 1.5 hours and cooled to room temperature before extraction with AcOEt $(x 3)$. The organic phases were washed with brine, dried over anhydrous $\mathrm{Na}_{2} \mathrm{SO}_{4}$ and the solvent was removed to give the desired crude product. Recrystallization from water/methanol afforded $1.91 \mathrm{~g}$ ( $80 \%$ yield) of $4 \mathbf{i}$ as a white solid. Mp: $183^{\circ} \mathrm{C}$. ${ }^{1} \mathrm{H} \mathrm{NMR}(300 \mathrm{MHz}$, $\mathrm{CDCl}_{3}$ ): $\delta 7.65$ (d, $\left.J=7.7 \mathrm{~Hz}, 1 \mathrm{H}, \mathrm{H} 3\right), 7.50$ (t, $\left.J=7.6 \mathrm{~Hz}, 1 \mathrm{H}, \mathrm{H} 5\right), 7.19$ (d, $J=7.9 \mathrm{~Hz}, 1 \mathrm{H}, \mathrm{H6}$ ), 7.12 (t, $J=7.6 \mathrm{~Hz}, 1 \mathrm{H}, \mathrm{H} 4), 7.03$ (br s, NH), 6.37 (s, 1H, H4'), $5.77\left(\mathrm{~s}, 1 \mathrm{H}, \mathrm{H} 6^{\prime}\right), 2.29\left(\mathrm{~s}, 3 \mathrm{H}, \mathrm{CH}_{3} \mathrm{~A}\right), 1.86\left(\mathrm{~s}, 3 \mathrm{H}, \mathrm{CH}_{3} \mathrm{~B}\right) \cdot{ }^{13} \mathrm{C}$ NMR $\left(75 \mathrm{MHz}, \mathrm{CDCl}_{3}\right)$ : $\delta 154.6,154.3,151.7,149.2,148.2,132.8,127.1$ (q, $J=5.2 \mathrm{~Hz}), 126.2 .125 .2$ (q, $J=28.9 \mathrm{~Hz}), 124.2$ (q, $J=271.5 \mathrm{~Hz}), 122.3$ 116.6, 109.5, 24.0, 20.7. IR (neat, $\left.\mathrm{cm}^{-1}\right): 1658(\mathrm{C}=\mathrm{N})$. El-MS m/z $308\left(\mathrm{M}^{+}\right)$. HRMS (ESI/QTOF) m/z: $[\mathrm{M}+\mathrm{H}]^{+}$calcd for $\mathrm{C}_{15} \mathrm{H}_{16} \mathrm{~F}_{3} \mathrm{~N}_{4}$ 309.1327; found 309.1336

Docking Studies: Docking computations were done with AutoDock4 $4^{[46]}$ with biased grid potentials as previously done for Rac1 $1^{[15,47]}$ using Rac1 crystal structure (PDBID: 1MH1). The docking cavity included Trp56 and where two hydrogen bond donor biases were placed for Asp 57 oxygen carbonyl atom with a $1 \mathrm{kcal} / \mathrm{mol}$ well. Box size was $44 \times 56 \times 64$ points with a $0.375 \AA$ A spacing between points. Simulations were performed for 100 runs, and the largest cluster results were kept. The energy was recomputed with unbiased maps to get a better estimation of the free energy of binding.

Chemoinformatic analysis: JChem for Excel was used for calculations of the structure-based properties (release 19.26.0.571, 2019, ChemAxon; http://www.chemaxon.com). Principal component and additional statistical analysis were performed using OriginPro 2017 (release b9.4.0.220 http://www.OriginLab.com).

Recombinant protein purification for in vitro assays: A pProEX HTTiam vector was used to express murine Tiam 1 (DH/PH domains, residues 1033 to 1406) as a fusion protein with an N-terminal 6xHis tag. A pGexRac 1 b plasmid was used to express human Rac1a as a fusion protein with an $\mathrm{N}$-terminal glutathione S-transferase (GST) tag. Rac1a sequence was subcloned into the expression vector pET28a (Novagen) to express Rac1a as a fusion protein with an $\mathrm{N}$-terminal $6 \times \mathrm{H}$ is tag. For recombinant protein production, E. coli BL21 (DE3) strain carrying the recombinant plasmids were grown at $37^{\circ} \mathrm{C}$ in $1 \mathrm{~L}$ of Terrific Broth until an optical density at 600 $\mathrm{nm}$ of 1.5 was reached before induction with $0.5 \mathrm{mM}$ IPTG. After induction, the culture was grown $16 \mathrm{~h}$ at $18{ }^{\circ} \mathrm{C}$ for protein expression. Cells were harvested by centrifugation and the expressed proteins were purified by affinity chromatography using GSTrap or HisTrap columns (GE 
HealthCare) respectively. Proteins were dialyzed and further purified by size exclusion chromatography using a Superdex 75 Preparative Grade Column (GE Healthcare). Protein concentration was determined spectrophotometrically using its molar extinction coefficient at $280 \mathrm{~nm}$, calculated using the Expasy ProtParam tool.

In vitro affinity precipitation of Rac-Tiam: The inhibitory effect of $4 \mathrm{i}$ and 2 compounds was tested in a complex formation assay. His- Tiam $(1 \mu \mathrm{g})$ was incubated with GST-Rac1 $(2 \mu \mathrm{g})$ in the presence 1D-142 (100 and 50 $\mu \mathrm{M}), 1 \mathrm{~A}-116(100 \mu \mathrm{M})$ or in the absence of any compound and $15 \mu \mathrm{L}$ of suspended glutathione-agarose beads. After incubation at $4{ }^{\circ} \mathrm{C}$ for $30 \mathrm{~min}$ samples were centrifuged and the supernatants were run in a SDS-PAGE gel. The presence of His-Tiam was detected by anti-His Western blotting.

In vitro Rac fluorescent mant-GTP exchange assay: $200 \mathrm{nM}$ purified His- Rac1-GDP was incubated at $30^{\circ} \mathrm{C}$ in an exchange buffer $(75 \mathrm{mM}$ $\mathrm{NaCl}, 10 \mathrm{mM} \mathrm{MgCl}, 20 \mathrm{mM}$ Tris. $\mathrm{HCl} \mathrm{pH} \mathrm{7.5,5 \%} \mathrm{DMSO).} \mathrm{Increasing}$ concentrations of $1 \mathrm{D}-142(100,200$ or $500 \mu \mathrm{M})$ or $1 \mathrm{~A}-116(2,100 \mu \mathrm{M})$ were included in the exchange buffer and incubated for 10 minutes before the addition of $500 \mathrm{nM}$ mant-GTP. The reaction was started by the addition of $200 \mathrm{nM}$ Tiam or the same volume of exchange buffer for the non-catalyzed control reaction. Nucleotide exchange was followed by the fluorescence increase of incorporated mant-GTP. Experiments were performed in an Aminco Bowman Series 2 fluorometer, using $355 \mathrm{~nm}$ excitation wavelength and collecting emission at $440 \mathrm{~nm}$ every 30 seconds. Rate constants $(\mathrm{k})$ were calculated using single-phase exponential equation $(\mathrm{f}=$ $f \_\max \left(1-e^{\wedge}(-k t)\right)$ to fit the fluorescence increase.

Cell culture and reagents: HT29 cells, A549 cells, PC 3 cells, MDA-MB231 cells and A375 cells were all obtained from ATCC (Rockville, MD, USA). HT29 cells, A549 cells, MDA-MB-231 cells and A375 cells were seeded in DMEM medium whereas PC3 cells were grown in RPMI 1640 medium (Gibco, Grand Island, NY, USA). Both media were supplemented with $10 \%$ fetal bovine serum (Gibco) and $50 \mu \mathrm{g} / \mathrm{ml}$ gentamicin. Culture cells were maintained in $5 \% \mathrm{CO}_{2}$ atmosphere at $37^{\circ} \mathrm{C}$. All cell lines were authenticated and tested for contamination.

The rabbit polyclonal anti-p65 and anti-IKBa antibodies, and peroxidaseconjugated goat anti-rabbit were obtained from Santa Cruz Biotechnology, USA. Secondary goat anti-rabbit FluoroLinkTM CyTM2 antibodies were purchased from GE Healthcare Bio-Sciences, Argentina. Mouse mAb antiactin and peroxidase-conjugated goat anti-rabbit were purchase from Calbiochem. Recombinant human TNF- $\alpha$ was obtained from PeproTech.

Cell proliferation assay: Cell viability was determined by colourimetric MTT (Sigma-Aldrich Co) assay. ${ }^{[48]}$ Cells were seeded in 96-well plates at a density of $1 \times 104$ cells/well and solutions containing different concentrations of the tested compounds were added. Each assay was done in triplicate. After $72 \mathrm{~h}$ of incubation, MTT solution $(5 \mathrm{mg} / \mathrm{mL}$ in distilled water) was added to cells in the culture medium and plates were incubated for $2 \mathrm{~h}$ at $37^{\circ} \mathrm{C}$. Then, the produced formazan was solubilized by the addition of $0.2 \mathrm{~mL}$ ethanol and absorbance values were immediately measured using an ELISA plate reader (Eurogenetics MPR-A 4i) at a test wavelength of $570 \mathrm{~nm}$ and a reference wavelength of $630 \mathrm{~nm}$. Results from each treated cell culture were normalized as a percentage of absorbance with respect to untreated controls. The drug concentration required to inhibit cell growth by $50 \%\left(\mathrm{IC}_{50}\right)$ was determined from concentrationresponse curves fitted with GraphPad Prism 6.0 software as previously reported. ${ }^{[49]}$ Results are expressed as the mean \pm standard deviation (SD) of three independent experiments.

Clonogenic assay: Study was performed as previously described. ${ }^{[49]}$ A549 cells were seeded in 6-well plates at a density of $1 \times 103$ cells/well and allowed to adhere for $24 \mathrm{~h}$. Then, cells were treated or not with 1D$142(25$ and $50 \square \mathrm{M})$ in complete media by duplicate. At $24 \mathrm{~h}$, culture medium was replaced with drug-free medium, and cells were grown for additional 7 days until visible colonies appeared. Finally, cells were rinsed with PBS, fixed with $10 \%$ formaldehyde for $10 \mathrm{~min}$ and stained with $1 \%$ crystal violet (20\% ethanol in distilled water). Colonies comprising at least 50 cells were scored and the images were recorded with a digital camera. ${ }^{[41]}$

Analysis of nuclear morphology: Cell nuclear apoptotic morphology was observed by staining with DAPI (Sigma-Aldrich Co) as previously described. ${ }^{[49]}$ A549 cells grown on glass coverslips in 24-well plates were incubated or not with 1D-142 (25 and $50 \square \mathrm{M}$ ) for $24 \mathrm{~h}$. After washes with PBS, cells were fixed with methanol for $10 \mathrm{~min}$ at $-20^{\circ} \mathrm{C}$ and stained with DAPI ( $4 \mu \mathrm{g} / \mathrm{ml}$ in PBS) for $5 \mathrm{~min}$ at room temperature protected from the light. Finally, coverslips were rinsed, mounted and imaged on a fluorescence microscope (Olympus BX51) with a DAPI filter. Apoptosis was determined according to characteristic nuclear morphology: the presence of apoptotic bodies, nuclear condensation, and fragmentation. ${ }^{[50]}$ Apoptotic cells were counted by NIH ImageJ program. ${ }^{[51]}$

Wound Healing Migration Assay: Cell migration was evaluated using an in vitro wound healing assay as described. ${ }^{[15]}$ Briefly, A549 cells were grown in 24-well plates until $90 \%$ confluence was observed. Subsequently, "scratch" wounds were created by scraping confluent monolayers with a sterile pipette tip. After 48 hour incubation in the presence or absence of 1D-142 (6.25 and $12.5 \mu \mathrm{M})$, cells were fixed. Pictures were taken at 0 and $48 \mathrm{~h}$ using a 10X objective. Ten random micrographs per well were obtained and migration area was quantified using NISElements 3.0 (Nikon) software. Wound closure measurements were normalized to the maximum scratch area.

Indirect immunofluorescence assay (IFI): The procedure for IFI was performed as previously described. ${ }^{[52]}$ Subconfluent A549 cells grown on glass coverslips in 24-well plates were fixed with methanol for $10 \mathrm{~min}$ at $-20^{\circ} \mathrm{C}$. After three washes with PBS, the coverslips were inverted on a drop of diluted primary antibody for $30 \mathrm{~min}$ at $37^{\circ} \mathrm{C}$, and then returned to culture dishes and subjected to three additional washes with PBS Afterwards, cells were incubated with diluted secondary antibody for 30 $\mathrm{min}$ at $37^{\circ} \mathrm{C}$. Nuclei were counterstained with DAPI $(4 \mu \mathrm{g} / \mathrm{ml}$ in PBS) for 5 $\mathrm{min}$ at room temperature protected from the light. Finally, coverslips were rinsed, mounted and photographed with an Olympus BX51 with epifluorescence optics.

Western blot analysis: Immunoblot procedure was performed as described. ${ }^{[52]}$ Whole extracts from A549 cells grown in 24-well plates were loaded on $10 \%$ sodium dodecyl sulphate-polyacrilamide ge electrophoresis (SDS-PAGE) and transferred onto polyvinylidene fluoride (PVDF) membranes for 60 min at $75 \mathrm{~mA}$. Membranes were blocked in PBS containing $5 \%$ defatted milk overnight and then incubated with diluted primary antibodies for $2 \mathrm{~h}$ at $37{ }^{\circ} \mathrm{C}$. After washing, membranes were incubated with diluted peroxidase conjugated antibodies for $1.5 \mathrm{~h}$ at $37^{\circ} \mathrm{C}$. The immunoreactive bands were visualized using an enhanced chemiluminesence system (ECL, PerkinElmer).

In vivo tumor growth and survival studies: A549 cells were injected subcutaneously $(2 \times 106$ in $100 \mu \mathrm{L}$ PBS $)$ into the right posterior leg of male athymic nude mice (nu/nu, 5-6 weeks old). Treatment was initiated when the subcutaneous tumors reached an average size of $50 \mathrm{~mm}^{3}$. Mice were treated every other day with $1 \mathrm{D}-142(10 \mathrm{mg} / \mathrm{kg} / \mathrm{day})$ or with vehicle $(12.5 \%$ Cremophor EL, $12.5 \%$ DMSO as an aqueous suspension) by intra peritoneal injection. Body weight and general health were monitored twice a week. Standard survival criteria were applied including severe lethargy, $20 \%$ weight loss, tumor burden $>2,000 \mathrm{~mm}^{3}$ and/or difficulty breathing Survival data was analyzed using GraphPad Prism software. All differences between treatment groups were analyzed by two-way ANOVA.

Animal Studies: All animal studies described here were performed according to the Institutional Committee for the Care and Use of Laboratory Animals of the Austral University Translational Medicine Research Institute (CICUAL-IIMT) approved protocol \#2018-03 and followed University Austral animal care procedures in accordance with the 
National Institutes of Health guide for the care and use of Laboratory animals (NIH Publications No. 8023, revised 1978).

\section{Acknowledgements}

This work was partly supported by Agencia Nacional de Promoción Científica y Tecnológica (ANPCyT) - Fondo para la Investigación Científica y Tecnológica (FONCyT) PICT-201-0362 to MJC and PICT-2018-1036 to JB, Consejo Nacional de Investigaciones Científicas y Técnicas (CONICET) PIP2014-2016 to MJC) and by Instituto Nacional de Tecnología Industrial (INTI).

\section{Author contributions}

The manuscript was written through contributions of all authors.

\section{Conflict of interest}

The authors declare no conflict of interest.

Keywords: Rac1 inhibitors • N,N'-disubstituted guanidines • protein-protein interactions inhibitors $•$ lung cancer

[1] S. J. Heasman, A. J. Ridley, Nat. Rev. Mol. Cell Biol. 2008, 9, 690-701.

[2] M. G. Kazanietz, M. J. Caloca, Cancer Res. 2017, 77, 5445-5451.

[3] V. Casado-Medrano, M. J. Baker, C. Lopez-Haber, M. Cooke, S. Wang, M. J. Caloca, M. G. Kazanietz, Biochem. Soc. Trans. 2018, 46, 10031012.

[4] D. Hanahan, R. A. Weinberg, Cell 2011, 144, 646-674.

[5] A. J. Hodge, R. G.; Ridley, Nat. Rev. Mol. Cell Biol. 2016, 17, 496-510.

[6] A. M. A.P. Porter, A. Papaioannou, Small GTPases 2016, 7, 123-138.

[7] Y. Zhou, Q. Liao, Y. Han, J. Chen, Z. Liu, H. Ling, J. Zhang, W. Yang, L. Oyang, L. Xia, L. Wang, H. Wang, L. Xue, H. Wang, B. Hu, J. Cancer 2016, 7, 2100-2109.

[8] M. Krauthammer, Y. Kong, B. H. Ha, P. Evans, A. Bacchiocchi, J. P. McCusker, E. Cheng, M. J. Davis, G. Goh, M. Choi, S. Ariyan, D. Narayan, K. Dutton-Regester, A. Capatana, E. C. Holman, M. Bosenberg M. Sznol, H. M. Kluger, D. E. Brash, D. F. Stern, M. A. Materin, R. S. Lo, S. Mane, S. Ma, K. K. Kidd, N. K. Hayward, R. P. Lifton, J. Schlessinger, T. J. Boggon, R. Halaban, Nat. Genet. 2012, 44, 1006-1014.

[9] T. Zou, X. Mao, J. Yin, X. Li, J. Chen, T. Zhu, Q. Li, H. Zhou, Z. Liu, Clin. Genet. 2017, 91, 520-528.

[10] G. Zhu, Z. Fan, M. Ding, H. Zhang, L. Mu, Y. Ding, Y. Zhang, B. Jia, L. Chen, Z. Chang, W. Wu, Oncogene 2015, 34, 5971-5982.

[11] D. Vigil, J. Cherfils, K. L. Rossman, C. J. Der, Nat. Rev. Cancer 2010, 10, 842-857.

[12] T. W. Traut, Mol. Cell. Biochem. 1994, 140, 1-22.

[13] J. L. Gray, F. von Delft, P. E. Brennan, Angew. Chem. Int. Ed. 2020, 59, 6342-6366.

[14] J. Ding, F. Yang, W. F. Wu, Medicine (Baltimore). 2019, 98, e17529.

[15] G. A. Cardama, M. J. Comin, L. Hornos, N. Gonzalez, L. Defelipe, A. G. Turjanski, D. F. Alonso, D. E. Gomez, P. L. Menna, Anticancer. Agents Med. Chem. 2014, 14, 840-51.

[16] Y. Gao, J. B. Dickerson, F. Guo, J. Zheng, Y. Zheng, Proc. Natl. Acad. Sci. 2004, 101, 7618-7623.

[17] N. Ferri, A. Corsini, P. Bottino, F. Clerici, A. Contini, J. Med. Chem. 2009, 52, 4087-4090.

[18] B. L. Montalvo-Ortiz, L. Castillo-Pichardo, E. Hernández, T. HumphriesBickley, A. De La Mota-Peynado, L. A. Cubano, C. P. Vlaar, S Dharmawardhane, J. Biol. Chem. 2012, 287, 13228-13238.
[19] A. Colomba, S. Giuriato, E. Dejean, K. Thornber, G. Delsol, H. Tronchère F. Meggetto, B. Payrastre, F. Gaits-lacovoni, Blood Cancer J. 2011, 1 $1-7$.

[20] G. Karpel-Massler, M. A. Westhoff, S. Zhou, L. Nonnenmacher, A Dwucet, R. E. Kast, M. G. Bachem, C. R. Wirtz, K. M. Debatin, M. E. Halatsch, Mol. Cancer Ther. 2013, 12, 1783-1795.

[21] T. Yoshida, Y. Zhang, L. A. Rivera Rosado, J. Chen, T. Khan, S. Y. Moon B. Zhang, Mol. Cancer Ther. 2010, 9, 1657-1668.

[22] S. Dütting, J. Heidenreich, D. Cherpokova, E. Amin, S. C. Zhang, M. R. Ahmadian, C. Brakebusch, B. Nieswandt, J. Thromb. Haemost. 2015, 13, 827-838.

[23] N. Ferri, S. K. Bernini, A. Corsini, F. Clerici, E. Erba, S. Stragliotto, A. Contini, Medchemcomm 2013, 4, 537-541.

[24] T. Humphries-Bickley, L. Castillo-Pichardo, F. Corujo-Carro, J. Duconge, E. Hernandez-O'Farrill, C. Vlaar, J. F. Rodriguez-Orengo, L. Cubano, S Dharmawardhane, J. Chromatogr. B Anal. Technol. Biomed. Life Sci. 2015, 981-982, 19-26.

[25] T. Humphries-Bickley, L. Castillo-Pichardo, E. Hernandez-O-Farrill, L. D. Borrero-Garcia, I. Forestier-Roman, Y. Gerena, M. Blanco, M. J. RiveraRobles, J. R. Rodriguez-Medina, L. A. Cubano, C. P. Vlaar, S. Dharmawardhane, Mol. Cancer Ther. 2017, 16, 805-818.

[26] Y. Gao, J. Xing, M. Streuli, T. L. Leto, Y. Zheng, J. Biol. Chem. 2001 276, 47530-41.

[27] P. Lorenzano Menna, D. Alonso, D. Gomez, M. Comin, WO2013053726 (A1) - PHENYL-GUANIDINE DERIVATIVES, 2012.

[28] G. Cardama, N. Gonzalez, M. Ciarlantini, L. Gandolfi Donadio, M. J. Comin, D. Alonso, P. Lorenzano Menna, D. Gomez, Onco. Targets. Ther 2014, 2021-2033.

[29] M. Cabrera, E. Echeverria, F. R. Lenicov, G. Cardama, N. Gonzalez, C Davio, N. Fernández, P. L. Menna, Oncotarget 2017, 8, 98509-98523.

[30] N. Gonzalez, G. A. Cardama, M. J. Comin, V. I. Segatori, M. Pifano, D F. Alonso, D. E. Gomez, P. L. Menna, Cell. Signal. 2017, 30, 154-161.

[31] T. A. Wenderski, C. F. Stratton, R. A. Bauer, F. Kopp, D. S. Tan, in Chem Biol. Methods Protoc. (Eds.: J.E. Hempel, C.H. Williams, C.C. Hong), 2015, pp. 225-242.

[32] C. F. Stratton, D. J. Newman, D. S. Tan, Bioorg. Med. Chem. Lett. 2015 25, 4802-4807.

[33] A. R. Katritzky, B. V Rogovoy, Arkivok 2005, iv, 49-87.

[34] A. H. Moustafa, W. W. Ahmed, A. Khodairy, J. Heterocycl. Chem. 2017, 54, 3490-3497.

[35] O. Foussard-Blanpin, G. Uchida-Ernouf, J. Anatol, J. Berecoechea, Eur. J. Med. Chem. 1979, 14, 215-218.

[36] B. R. Linton, A. J. Carr, B. P. Orner, A. D. Hamilton, J. Org. Chem. 2000, 65, 1566-1568.

[37] J. Zhang, Y. Shi, P. Stein, K. Atwal, C. Li, Tetrahedron Lett. 2002, 43, 57-59.

[38] D. K. Worthylake, K. L. Rossman, J. Sondek, Nature 2000, 408, 682 688.

[39] T. Zhang, N. Wang, Oncol. Res. 2018, 26, 1191-1200.

[40] N. Kaneto, S. Yokoyama, Y. Hayakawa, S. Kato, H. Sakurai, I. Saiki, Cancer Sci. 2014, 105, 788-794.

[41] N. A. P. Franken, H. M. Rodermond, J. Stap, J. Haveman, C. Van Bree Nat. Protoc. 2006, 1, 2315-2319.

[42] A. Gastonguay, T. Berg, A. Hauser, N. Schuld, E. Lorimer, C. Willimas, Cancer Biol. Ther. 2012, 13, 647-656.

[43] M. S. Hayden, S. Ghosh, Cell 2008, 132, 344-362

[44] T. Sterling, J. J. Irwin, J. Chem. Inf. Model. 2015, 55, 2324-2337.

[45] M. K. Rauf, A. Talib, A. Badshah, S. Zaib, K. Shoaib, M. Shahid, U. Flörke, Imtiaz-Ud-Din, J. Iqbal, Eur. J. Med. Chem. 2013, 70, 487-496.

[46] G. M. Morris, H. Ruth, W. Lindstrom, M. F. Sanner, R. K. Belew, D. S Goodsell, A. J. Olson, J. Comput. Chem. 2009, 30, 2785-2791.

[47] J. P. Arcon, L. A. Defelipe, C. P. Modenutti, E. D. López, D. Alvarez Garcia, X. Barril, A. G. Turjanski, M. A. Martí, J. Chem. Inf. Model. 2017 57, 846-863.

[48] F. Denizot, R. Lang, J. Immunol. Methods 1986, 89, 271-277.

[49] F. Alonso, M. J. Quezada, G. F. Gola, V. Richmond, G. M. Cabrera, A A. Barquero, J. A. Ramírez, ChemMedChem 2018, 13, 1732-1740. 
[50] Y. Sawai, H. Murata, M. Horii, K. Koto, T. Matsui, N. Horie, Y. Tsuji, E. Ashihara, T. Maekawa, T. Kubo, S. Fushiki, Oncol. Rep. 2013, 29, 941 945.

[51] "NIH Image J program," can be found under https://imagej.net/Welcome

[52] C. A. Bueno, A. A. Barquero, H. Di Cónsoli, M. S. Maier, L. E. Alché, Virus Res. 2009, 141, 47-54. 


\section{Entry for the Table of Contents}

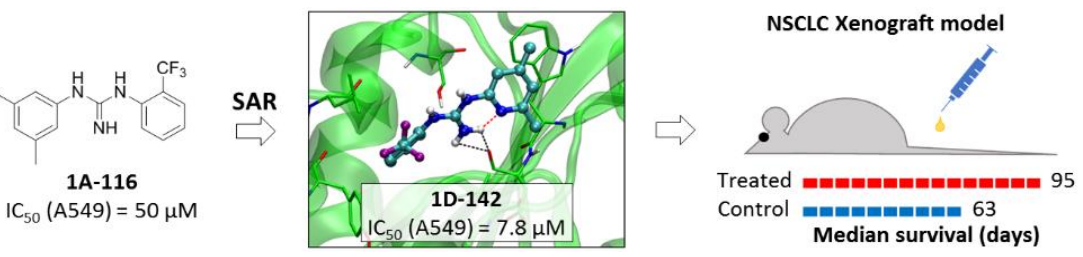

The structure-activity relationship within a new family of N,N'-disubstituted guanidine as Rac1-GEF interaction inhibitors was studied. New analogue 1D-142 showed superior antiproliferative activity in several human cancer cell lines. The results reported herein provide the first proof-of-principle supporting the use of a Rac1 inhibitor in a lung cancer animal model, reducing tumor growth and increasing animal survival in an A549 xenograft model. 